DOI https://doi.org/10.32841/2409-1154.2021.49-2.27

\author{
Sharova T.M., \\ Doctor of Philology, \\ Professor at the Department of Social Sciences and Humanities \\ Dmytro Motornyi Tavria State Agrotechnological University
}

\author{
Mamchur E. O., \\ Student \\ Bogdan Khmelnitsky Melitopol State Pedagogical University
}

\title{
THE PHENOMENON OF INCLUSION IN IRINA MORIKVAS'S STORY “MAGDA AND THE WIND”
}

Summary. The article focuses on the literature dealing with inclusion. The work of the modern Ukrainian writer I. Morikvas is taken as an example. The writer of the novel "Magda and the Wind" shows life, strength of spirit and faith in a bright future on the example of a little girl Magda, who had been chairbound since her childhood. I. Morikvas calls to fight his fears; to dream in spite of a difficult inner situation; wait for the "same" wind; teach people to value life.

The article provides information that Magda is the heroine of Morikvas's novel - the girl who loved to dream the most in her life. In her dreams, she was not chairbound. The writer emphasizes that she dreams of traveling, but there is no possibility, because she is chairbound. Most of all she imagined herself as an ordinary girl surrounded by friends. In her dreams she goes to school, rides a bicycle. As Magda was confined to a wheelchair, she did not often go outside. Looking out the window at everything in the street, she loved watching the birds most of all. She admired that they could just fly anywhere. She could talk to them, but in silence, as they flew to her on the windowsill to eat the seeds.

In her novel the writer uses illustrations as an auxiliary component in creating the chairbound girl's story of life. I. Morikvas makes the story accessible to young children. Looking at the illustrations, they empathize with all Magda's ups and downs. While reading the text, you can confirm the girl's mood and feel all the pain that Magda felt one more time. The presence of illustrations to the story "Magda and the Wind" is extremely useful for adult audiences as well.

Having made the final open, Irina Morikvas resorted to an interesting psychological trick. She wants the reader to decide for himself how Magdina's fate turned out in the future. Iryna Morikvas's philosophical story "Magda and the Wind" was written to show by the chairbound girl example that it is necessary to believe in the best. The writer portrays Magda as strong and enduring, able to withstand a storm of disappointments.

Key words: inclusion, wheelchair, philosophy of life, literary text, despair, hope.

Formulation of the problem. Inclusion is a process that reveals the question of people's understanding with disabilities. Inclusion explains important aspects of socialization and people's adaptation in society. Recently, you can oftener see people with disabilities surrounded by healthy full-fledged personalities. It is important to understand that regardless of whether or not a person has physical disabilities or special needs - he has the right to life in the proper sense of the word. By providing equal opportunities for life and self-realization in society, every member of the society receives positive changes. People with special needs have certain complexes, which inhibits their socialization and ability to develop in society.

Analysis of recent research. For the present, the topic of inclusion has been repeatedly studied by European and domestic researchers. It can be explained by the fact that the process of inclusion is extremely multifaceted and therefore has been repeatedly studied. Thus, Berendeeva A.I. in her article "The scope of the "inclusion" definition" focused on identifying the inclusion place in a modern society [1]. Researchers Lapina M.D. and Boyko E.V. in their work "The inclusion as a resource for people with disabilities" considered inclusion as a way of «peculiar» people to live in the environment of physically unlimited citizens [2]. The topic of inclusion occupies a special place in the literature about "special" people. Thus, scientists Sharov S.V. and Sharova T.M. in their works focused on the artistic space of inclusion as means of social people with disabilities rehabilitation. At the same time, the researchers emphasized the capabilities of people with disabilities [3; 4].

The purpose of the article. The aim of the article is to show people with special needs in literature, particularly in I. Morikvas's novel "Magda and the Wind".

Presenting main material. The issue of inclusion can be explored as a subject through versatile vision of the problem. Moreover that positive dynamics of this issue understanding can be provided by reading literary texts, where the main characters are people with special needs. Such literature is called inclusive. Contemporary Ukrainian and foreign writers in literary texts repeatedly raise the issue of people with disabilities and special needs of socialization. For example, Victoria Nadikto is a Ukrainian author who writes about the life of a teenaged girl with disabilities. The main character of "The Adventures of Dasha and Tina" suffers from cystic fibrosis and despite this the girl does not lose positiveness and faith in the better future [5].

English novelist Jojo Moyes in the novel "See you" tells about the life of a chairbound man. The protagonist of the novel does not imagine his life in a wheelchair and therefore, his head is full of thoughts about euthanasia. At the end of the novel, he will die and before that he will be able to change one person's life. In the novel we trace one of the main features of an inclusive personthe ability to change the value system of any personality [6]. Thus, we can confirm that this topic is relevant, and the issue of inclusion in the literature has not been studied yet. 
The theme of inclusion is reflected in Irina Morikvas's works as well. In 2017, the writer introduces the world to the inclusive people history (fig. 1). Today, there are no detailed works that would allow to agree on a comprehensive analysis of the writer's creative activity. To understand I. Morikvas' creative world view, we can get acquainted only with small anonymous responses where the authors present their own vision of the question dealing with I. Morikvas' creativity.

Iryna Morikvas is not only engaged in writing. The world knows her as a famous artist and illustrator. For 10 years, Irina

\section{Irina Morikvas}

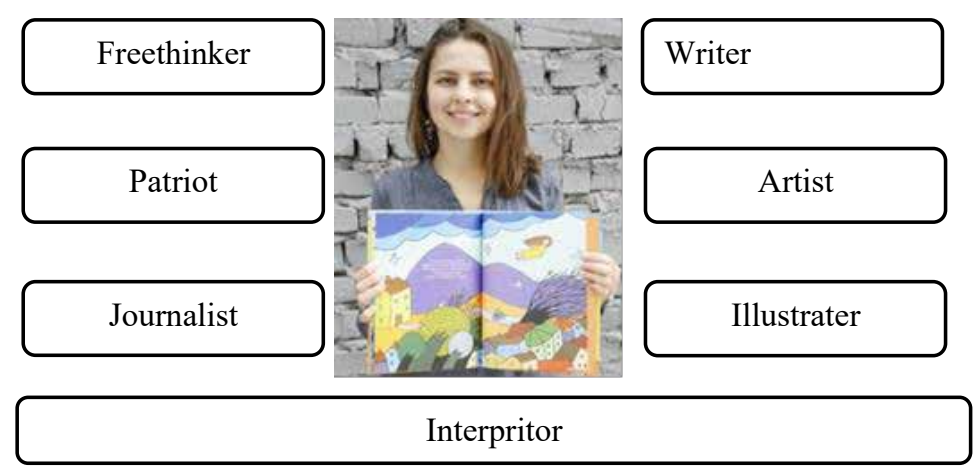

Fig. 1. Irina Morikvas

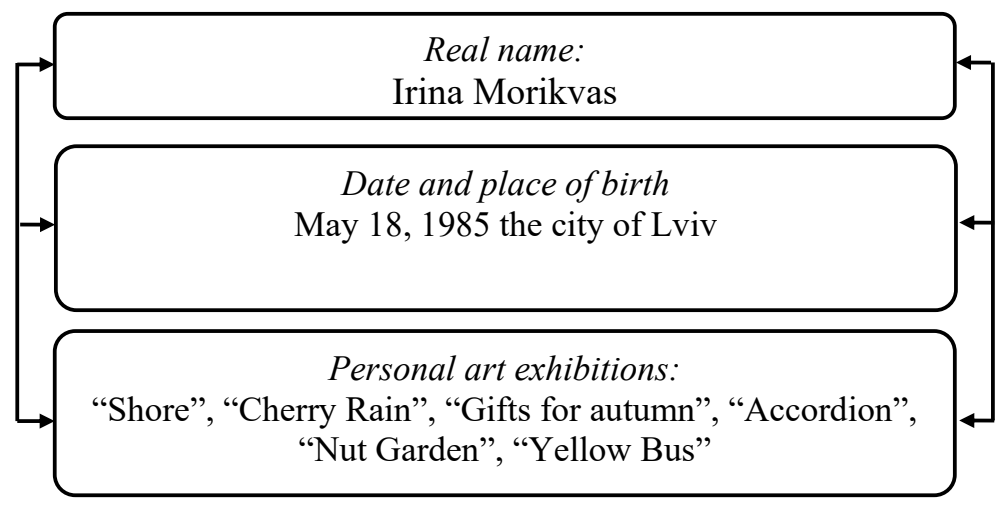

Fig. 2. Information about Irina Morikvas

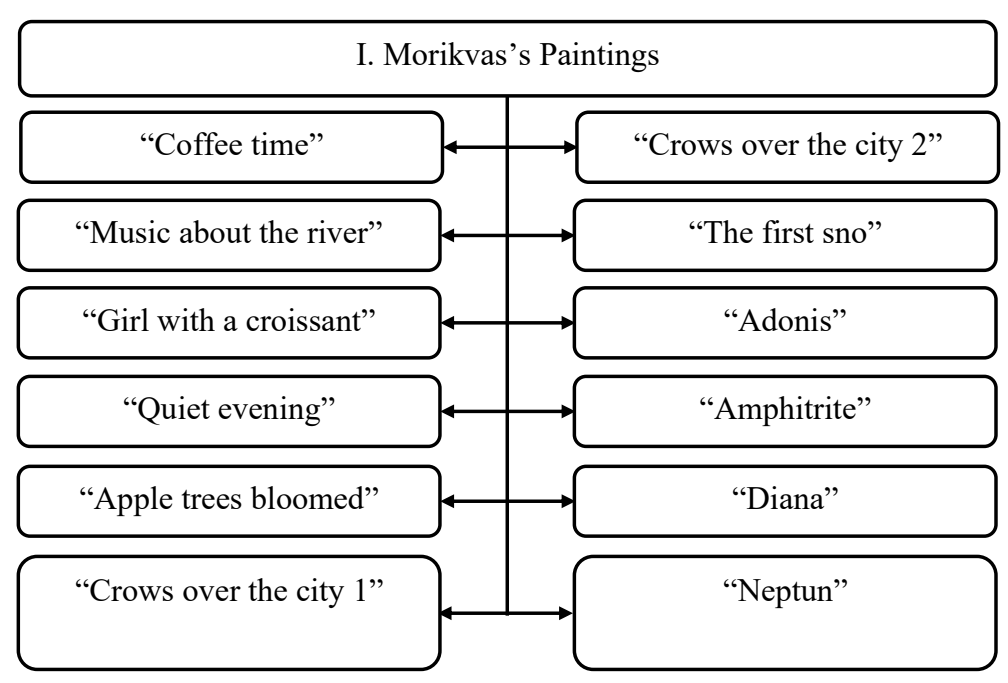

Fig. 3. Paintings by Irina Morikvas
Morikvas' best friends have been a brush, paints and paper [7]. Iryna Morikvas is a journalist by profession. Today she lives in Lviv with her family (fig. 2).

Iryna Morikvas received world recognition due to her artistic activity. The art world opened its doors to Iryna Morikvas by chance - she saw children drawing at an art school. For the present Irina Morikvas has a significant number of paintings (fig. 3).

Thanks to the unsurpassed talent and originality of her paintings, Iryna Morikvas has won in the field with which she decided to connect her life. (fig. 4).

Iryna Morikvas is the author of solo exhibitions in Ukraine and a participant in exhibitions outside Ukraine [8]. The writer actively participated in exhibitions in 2006-2010. However, we can say that it was a brilliant career in the field of literature, art and artistic creation (fig. 5).

I. Morikvas's debut in writing was the publication of the book "Magda and the Wind". The author writes the life story of a little chairbound girl. She is Magdina; she falls asleep every day and wakes up hoping that one day her life will change for the better.

Anyone who has become acquainted with Magdina's story can feel pain and anxiety. Svitlana Pyrkalo, as a member of the Jury Book of the Year, writes that Magda's story is touching, tragic and takes place in a modern children's literature, because it is a sign of healthy literature. However, she is concerned about a number of questions that each reader must answer himself [9]. After reading the story, they are overwhelmed with thoughts that the story is of sad character, but the sad is the story of Magdina's life. Most likely, this is not a story, but a philosophical sketch [10]. Iryna Pasko emphasizes that it was difficult for Magda not only in physical way but morally as well. The relations that developed in Magdina's family were not very friendly [11].

Irina Morikvas was inspired to write about a girl in a wheelchair, by a real-life story. "My son and I went out of the kindergarten two years ago, when he was 4, and a girl in a wheelchair met us in the town. And her son was very interested in the fact why the girl was taken in a wheelchair, even though she looked like a schoolgirl. We talked a lot on this topic with him; I was very concerned about it" [12]. After such a meeting, the writer created a whole book, which was supplemented with illustrations, with the help of which it was easier to understand the theme of the work, even for preschool children.

Writing a philosophical story on the topic of inclusion, Iryna Morikvas encourages to read this story not only children but adults as well. The writer sets Magda as an example to all people. The poetics of the work is presented in detail in fig. 6 .

Magda is the girl who loved to dream the most in her life. In her dreams, she was not chairbound. She dreams of traveling, but there is no opportunity, because she is chairbound. The most often, she imagined herself an ordinary girl who has friends, she does not move with the help of a wheelchair. In her dreams she goes to school, rides a bicycle. 
Sometimes, she dreamt so much that she didn't even notice how the day turned into night. Magda dreamed and hoped that one day «her» wind would come and lift her into the clouds, where she could be an ordinary girl. She often wrote down her thoughts into a notebook. She also wrote down dreams about the ability to fly. "I can fly, but I'm afraid of heights. Sometimes a strong March wind lifts me high and high, up to the clouds, but I immediately come back. I sit on the branches of trees and listen to the wind rustle the leaves and my hair" $[13, p .6]$.

As Magda was chairbound, she did not often go outside. Looking out of the window at everything that happened in the street, she loved watching the birds most of all. She admired that they could just fly somewhere. She could talk to them, but in silence, as they flew to her and sat on the windowsill to eat the seeds. "Magda watched the birds fly, and she also wanted to fly. To fly every time you want to take a walk in the park or play hide and seek with the neighboring children" [13, p. 12].

When Magda's parents took her to the park, she seemed to find herself in another world. Looking at the active lifestyle of other people - she found herself in another world. She wanted to dance but the wheelchair became an obstacle in her real life. But in her dreams, nothing could stop her from spinning in the dance. But dreams could not save her from the judgmental looks of passers-by, who in all their forms sympathized with her situation. "But as soon as she noticed someone's sympathetic or judgmental looks - she became sad and she really wanted to go home" [13, p. 13].

Magda was the very person who believed and knew that the most cherished dream would surely come true. Further, the events of the story unfold in such a way that one morning a storm broke out in the city that was ready to lift even a man. Looking out of the window, Magda was happy. She waited for the same wind. The wind of her dream that can change her life. "She knew that dreams come true and that each dream has its own - a special wind" [13, p. 23].

Compositionally, the work is constructed through an expositional acquaintance with Magda, the story about girl's dreams and hopes, her attachment to the wheel-chair and the final meeting of the main character of the story with the wind (fig. 7).

Having made the final open, Irina Morikvas resorted to an interesting psychological trick. She wants the reader to decide for himself how Magdina's fate would turn the future. "Some say that Magda will become a swimmer and win a gold medal at the Parolympic Games. Chi - Magda will fly to Japan" $[13, \mathrm{p}$. 24]. Thus, the writer pushes readers to think more deeply about the theme and issues of the work (fig. 8).

Not less interesting is the fact that Irina Morikvas supplemented the text with illustrations. They is not just drawings. This is the way of visualization that best composes a picture from the written text. Every action, thought, word, dream, mood, and feeling of Magdina in the story - all this finds its place through illustrations.

As the author begins to introduce Magda to the reader, an illustration of abig world and a little girl Magda appears in front of her eyes. The girl's mood at this moment is depicted in dark tones, because it seems to her that no one notices her in this world. Then, when the writer says that Magda loves to dream - the illustration shows Magda in high spirits. She is
Irina Morikvas's Victory in competitions

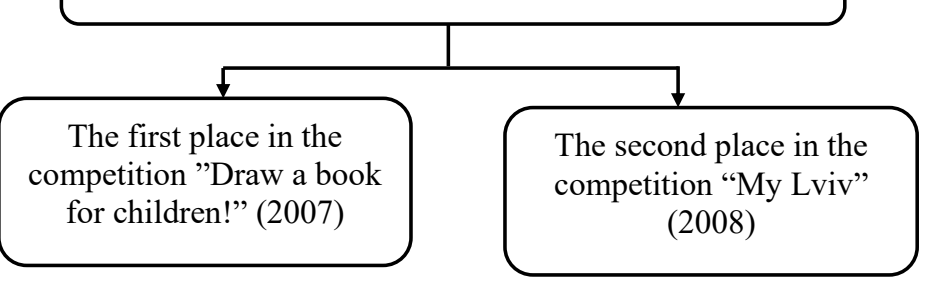

Fig. 4. Competitions where Iryna Morikvas won

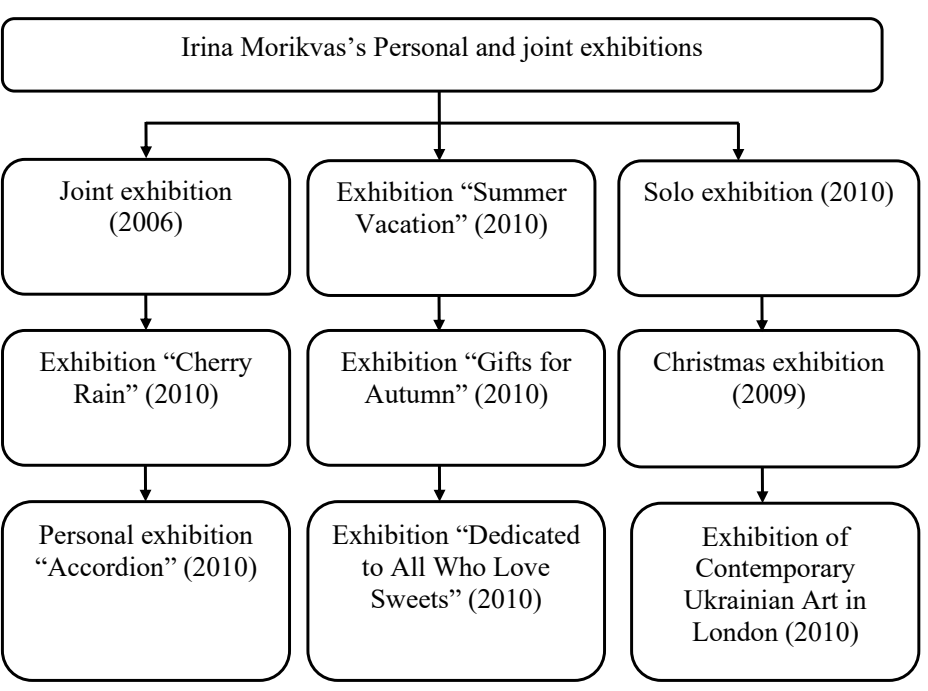

Fig. 5. Personal and joint exhibitions of I. Morikvas

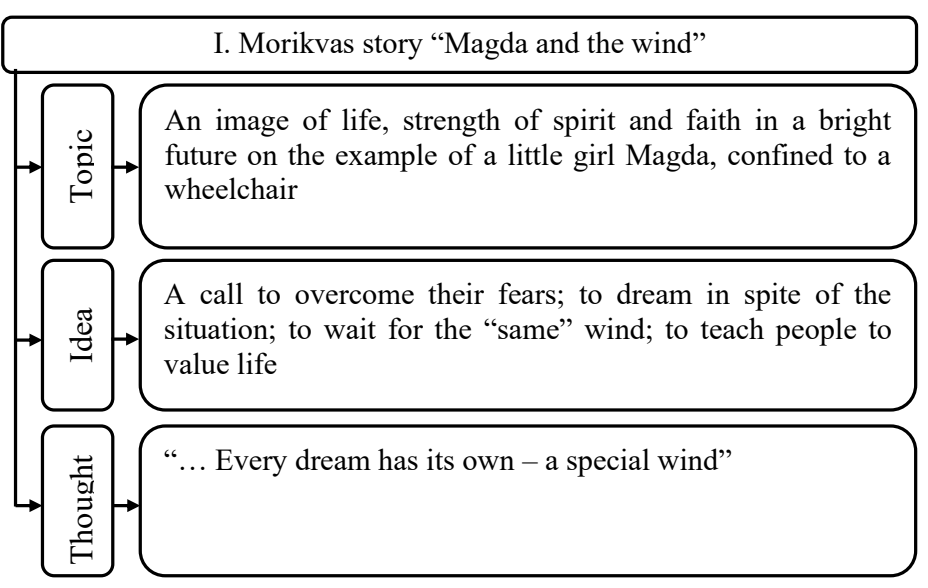

Fig. 6. The story of I. Morikvas «Magda and the wind»

happy because in her dreams she can fly and can travel all over world. The girl is like a bird that can find herself somewhere at any time.

When Iryna Morikvas tells that Magda sat in a wheelchair and rarely went out, she backs up her text with a sad picture. This illustration shows Magda confined to a wheelchair, talking silently with birds and watching the life of the world on the other side of the window. It is also interesting is the illustration, which is worth the attention of many people - this is an illustration where Magda, walking in the park, as if trying to hide from the sympathetic gazes of passers-by. She does not want to be pitied, and the author 
Composition of the story by I. Morikvas "Magda and the wind"

Exposition: Acquaintance with the girl Magda

Node: Dreams and hopes meeting with the wind of change

Culmination: Magda in a wheelchair; raising of a storm in the city

Anagnorisis: Making Magda's most cherished dream come true is the meeting the wind of change

Fig. 7. The composition of the story by I. Morikvas "Magda and the wind"

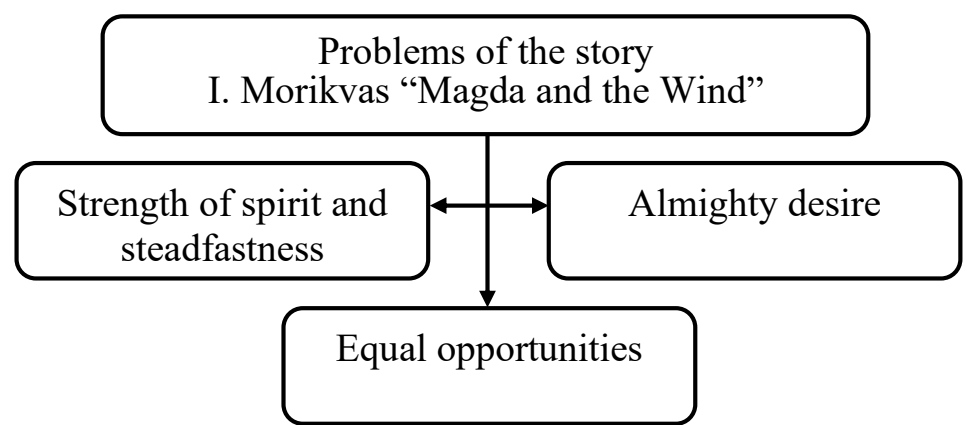

Fig. 8. Problems of the story I. Morikvas "Magda and the wind"

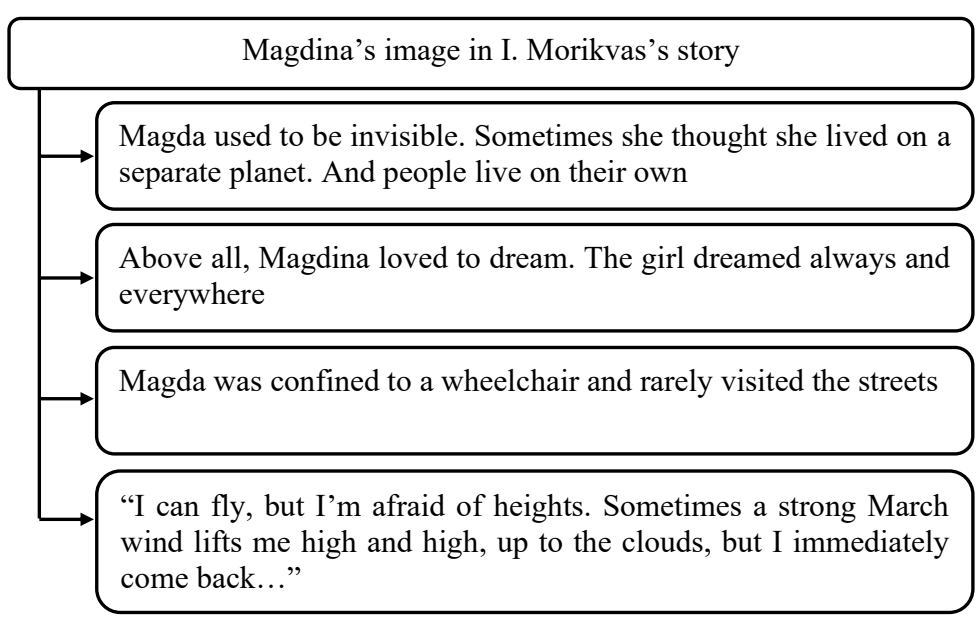

Fig. 9. Magdina's image in I. Morikvas's story

of the story does not want that too. Iryna Morikvas tried to portray Magda as strong and enduring, and she succeeded. Magda is an example of a person who was able to wait for changes in her life, and while she waited she did not get in despair. The illustration in which Magda waits for the wind and soars high into the sky is painted with bright colors. It is in this picture that Magda is extremely happy, because it is not just a dream, it is her reality. Not only the drawings in the middle of the book are interesting, but also the cover, which depicts Magda sitting on a tree waiting for the wind of change.
Using illustrations as an auxiliary component in creating the girl's life story in a wheelchair, Irina Morikvas makes the story accessible to young children. Looking at the illustrations, they empathize with all the ups and downs along with Magda. Reading the text, you can once again confirm the girl's mood and feel all the pain that Magda felt.

The presence of illustrations to the story "Magda and the Wind" is extremely useful for adults. While reading the work, everyone imagines "his" Magdina, the city where she lived, the birds she talked to. However, no less interesting is the image of Magda in the vision of Irina Morikvas, the reflection of which can be seen not only through the lines of text, but also through drawings. Analyzing not only the text but also the illustrations, it is possible to schematically depict the image of Magdina (fig. 9).

Iryna Morikvas's philosophical story "Magda and the Wind" was written to show on the example of a girl in a wheelchair that it is necessary to believe in the best. The writer portrays Magda as strong and resilient who is able to withstand a storm of disappointments. Magdina is not just the heroine of the story "Magda and the Wind", first of all, she is an example of a girl who believed that she could leave a wheelchair. This is a girl who knew for sure that the time would come and she would be able to walk fully without the need for outside help.

Conclusions. By writing a story about the life story of a girl in a wheelchair, Iryna Morikvas changed the lives of many people. Irina Morikvas's Magda is able to change any person's value system. The girl teaches us not to lose hope inspite on the fact that it does not happen there, because the wind of change will definitely knock on everyone's door.

\section{References:}

1. Берендєєва А.І. Сфера застосування дефініції «інклюзія». Південноукраӥнський правничий часопис. 2017. № 4. C. 19-21.

2. Лапіна М.Д., Бойко Є.В. (2020) Інклюзія як ресурс для людей з інвалідністю. Reporter of the priazovskyi state technical university. Section: Socially-humanitarian sciences and public administration 2020 Issue 5. C. 36-40.

3. Шаров С.В., Шарова Т.М. Художній простір на тему інклюзії як засіб соціалізації в суспільстві. Пріоритетні напрямки розвитку сучасних педагогічних та психологічних наук : матеріали Міжнар. наук.-практ. конф., 9-10 серпня 2019 р., м. Одеса. 2019. С. 112-115.

4. Шарова Т.М. Художня література як засіб соціальної реабілітації людей $з$ обмеженими можливостями. Літні наукові підсумки 2019 року: XVIII Міжнародна науково-практична Інтернет конференція : тези доповідей, Дніпро, 5 червня 2019 р., 2019. С. $84-89$.

5. Пригоди Даші й Tiнi. URL: https://osmolovska.com/features/books/ item/192-pryhody-dashi-i-tini (дата звернення 21.04.2021). 5

6. До встречи с тобой (Мойес). URL: http://surl.li/tuuk (дата звернення 21.04.2021).

7. Виставка картин Ірини Мориквас «Гуашеве літо». URL: https:// lviv-online.com/ua/events/arts/vystavka-kartyn-iryny-morykvasguasheve-lito/ (дата звернення 21.04.2021). 
8. Картини Ірини Мориквас. URL: https://onlyart.org.ua/kupytykartyny-iryny-morykvas/ (дата звернення 21.04.2021.

9. Пиркало С. Куди забрав Магду вітер? URL: https://www.bbc.com/ ukrainian/features-41972107 (дата звернення 21.04.2021).

10. Кізима О. Відгук на книгу І. Мориквас «Магда i вітер». URL: https://www.yakaboo.ua/magda-i-viter.html\#tab-reviews (дата звернення: 26.03.2021).

11. Пасько I. Відгук на книгу. Магда і вітер by Ірина Мориквас. URL: https://www.goodreads.com/book/show/36286107 (дата звернення 21.04.2021).

12. Мориквас: це - книга про дівчинку, яка не може ходити, але може мріяти. URL: https://www.bbc.com/ukrainian/features41917499\#: : text=»Книга\%20про\%20дівчинку\%2C\%20яка\%20не,лише $\% 20$ тексту\% 2 С\%20але $\% 20$ й\%20ілюстрацій (дата звернення 21.04.2021).

13. Мориквас І. Магда і вітер. Вид-во : А-ба-ба-га-ла-ма-га. 2017.24 с.

Шарова Т. М., Мамчур С. О. Феномен інклюзії в оповіданні Ірини Мориквас «Магда і вітер»

Анотація. У статті акцентується увага на літературі на тему інклюзії. Як приклад узята творчість сучасної української письменниці I. Мориквас. Письменниця в художньому тексті «Магда і вітер» показує життя, силу духу та віру в райдужне майбутнє на прикладі маленької дівчини Магди, прикутої до інвалідного візка. І. Мориквас закликає до того, аби бороти свої страхи, мріяти попри важке внутрішне становище, дочекатися «того самого» вітру, навчити людей цінувати життя.

У статті подана інформація про те, що Магда - героїня твору I. Мориквас - дівчинка, яка найбільше за все у своєму житті любила мріяти. У мріях вона не була прикута до інвалідного візка. Письменниця акцентує на тому, що вона мріє мандрувати, але не може, бо прикута до візка. Частіше за все вона уявляла себе звичайною дівчинкою, в якої є друзі. У мріях вона ходить до школи, їздить на велосипеді. Через те, що Магда була прикута до візка, вона не часто бувала на вулиці. Дивлячись через вікно на все, що відбувається на вулиці, найбільше вона полюбляла спостерігати за птахами. Вона захоплювалася тим, що вони можуть просто взяти та полетіти куди завгодно. Вона могла 3 ними говорити, але мовчки в той час, коли вони прилітали до неї на підвіконня, аби поїсти насіння.

Художньому тексті письменниця використовує ілюстрації як допоміжний компонент у створенні історії життя дівчинки на візку. І. Мориквас робить оповідання доступним для дітей наймолодшого віку. Дивлячись на ілюстрації, вони співпереживають всі злети та падіння разом із Магдою. Читаючи текст, можна ще раз підтвердити побачений настрій дівчинки та відчути увесь біль, який відчувала Магда. Наявність ілюстрацій до оповідання «Магда і вітер», є надзвичайно корисними і для дорослої аудиторії.

Зробивши фінал відкритим, Ірина Мориквас вдається до цікавого психологічного прийому. Вона бажає, аби читач сам вирішив, як надалі склалася доля Магдини. Філософське оповідання Ірини Мориквас «Магда і вітер» написано для того, аби на прикладі дівчинки в інвалідному візку показати, що треба вірити в краще. Письменниця зображує Магду сильною та витривалою, яка зможе вистояти перед буревієм розчарувань.

Ключові слова: інклюзія, інвалідний візок, філософія життя, художній текст, розпач, надія. 